\title{
A new petrified pentalocular capsular fruit from the deccan intertrappean beds of Mohgaonkalan, M.P., India
}

\author{
A. S. Khursel ${ }^{1}$ and S. D. Narkhede $^{2^{*}}$ \\ ${ }^{1}$ Department of Botany, ShankarlalAgrawal Science College, Salekasa, Gondia, (MS), India \\ ${ }^{2}$ Department of Botany, Government Institute of Science, Nagpur, (MS), India \\ *Corresponding author
}

\begin{tabular}{|c|c|}
\hline & A B S T R A C T \\
\hline $\begin{array}{l}\text { K e y w o r d s } \\
\text { Intertrappean, } \\
\text { Angiosperm, } \\
\text { Pentalocular. }\end{array}$ & \multirow{3}{*}{$\begin{array}{l}\text { The fossil angiospermic fruit reported was collected from Mohagaonkalan, } \\
\text { of Chhindwara district, M.P. locality belonging to upper most cretaceous } \\
\text { period.Pentalocular capsular fruit Pentaloculocar ponintertrappea is oblong } \\
\text { in shape. Each locule is separated by means of vertical septa with single } \\
\text { seed in each loculeand possessing persistent calyx and it shows well } \\
\text { preserved marginal placentation. The entire fruit measures } 3800 \mu \mathrm{m} \text { long and } \\
2500 \mu \mathrm{m} \text { broad. }\end{array}$} \\
\hline Article Info & \\
\hline $\begin{array}{l}\text { Accepted: } \\
20 \text { March } 2016 \\
\text { Available Online: } \\
10 \text { April } 2016\end{array}$ & \\
\hline
\end{tabular}

\section{Introduction}

The intertrappean flora is rich in fossil angiosperm. Many dicotyledonous capsular fruits have been reported so far, to name a few Enigmocarpon parijae (Sahni, 1943), Harrisocarpon sahnii (Chitaley \& Nambudiri, 1973), Sahniocarpon harrisii (Chitaley \& Patil, 1972), Daberocarpon gerhardii (Chitaley \& Sheikh, 1973), Deccanocarpon arnoldii (Paradkar\& Dixit, 1975), Loculocidocarpon chitaleii (Kapgate, 1999), Chitaleocarpon intertrappea (Kapgate, 2000) and Lythraceocarpon mohgaonese (Saxsena, 2004), Portulacaceocapon jamsavlii (Bhowal, Narkhede and Meshram,2011).

In this present study one more dicotyledonous capsular fruit with persistant calyx from
Deccan intertrappean beds of Mohgaonkalan is being investigated.

\section{Materials and Methods}

The petrified pentalocular fruit described as under was found preserved in a piece of black chert which was collected from the deccan Intertrappean beds of Mohgaonkalan, M.P., India. The anatomical details were studied by etching the chert with hydrofluoric acid and peel sections were prepared without grinding the material. The counter part was lost during breaking. The fruit appeared in longitudinal plane. The important stages of the fruit were photographed and camera lucida sketches were drawn. 


\section{Description}

\section{Fruit Morphology}

The present dicotyledonous petrified fruit exposed in longitudinal plane, after taking peels, it is observed that, fruit is obliquely placed. It is oblong in shape, pentalocular i.e. five locular with single seed in each locule, possessing persistant calyx. Each locule is seprated by means of vertical septa. Pericarp is multilayered and differentiated into epicarp, mesocarp\& endocarp hence capsular in nature. In L.S seed appears long \& elongated in shape and embryo is not preserved. The whole fruit measures $3800 \mu \mathrm{m}$ long and $2500 \mu \mathrm{m}$ in broad. (Plate Fig. 1\& Text Fig. 1)

\section{Fruit Anatomy}

The anatomical study of capsular fruit reveals following structure.

The fruit wall or pericarp is dry, smooth without any outgrowths. It is multilayered and differentiated into epicarp, mesocarp \& endocarp with $200 \mu \mathrm{m}$ in thickness. At some places in pericarp few canals are present. The epicarp is single layered, consisting of thick walled parenchymatous cells and measures $29 \mu \mathrm{m}$ in thickness. The middle layer mesocarp is multilayered consisting of long \& elongated thin walled parenchymatous cells, which are irregularly arranged with some dark depositions. It measures $96 \mu \mathrm{m}$ in thickness. Below mesocarp a single layer of endocarp is present consisting of thin walled parenchymatous cells and measures $22 \mu \mathrm{m}$ in thickness. In L.S. vascular supply is clearly observed in fruit wall (Plate Fig. 2\& Text Fig. 2).

The fruit is cut in oblique manner. It appears pentalocular in $1^{\text {st }}$ peel section and later on the number of locules start declining due to the disappearance of locule. The fruit appear tetralocular in $6^{\text {th }}$ peel section, trilocular in $15^{\text {th }}$ peel section, bilocular in $23^{\text {rd }}$ peel section and unilocular in $27^{\text {th }}$ peel section. All the five locules are seprated by means of vertical septa. Locule is long \& elongated in shape and broader towards its both ends. The size of all the five locules vary from each other. The average size of locule is $2100 \mu \mathrm{m}$ long and $600 \mu \mathrm{m}$ broad. Each locule incorporates single prominent seed.The septae are long and vertically straight. The average thickness of septae is $100 \mu \mathrm{m}$. The two septa join at the terminal end in a rounded curve manner forming the loculii. Thus, five septae separating the five chambers of fruit showing more or less same tissues as in the fruit wall.

Single seed is present in each locule. They are oval to elongated in shape and measures $1950 \mu \mathrm{m}$ to $500 \mu \mathrm{m}$ in size. Seed shows marginal placentation and occupy the complete space of the locule. (Plate Fig.3) Seed coat is differentiated into two integument, ie. outertesta\& inner tegma, which means seed is bitegmic in nature.The lumen of seed is filled up by endospermic tissue which is well preserved and made up of thin and thick walled parenchymatous tissue. Embryois not preserved; hence no comments could be given.

There is no sign of dehiscence observed in pericarp, locules and septa. Hence, it is clear that the present petrified fruit is indehiscent.

In longitudinal section, persistant calyx appears which arises from the base of the fruit and present on both the side of pentolocular fruit. They are broad at the basal portion and narrowing towards terminal portion. Each calyx is free from the fruit wall and measures $75 \mu \mathrm{m}$ in thickness. It consist of thick walled elongated 
parenchymatous cells having some dark brown depositions and shows xylem strands at the basal part of the calyx. (Plate Fig. 1\& Text Fig 1)

\section{Discussion and Identification}

Thus present dicotyledonous, pentalocular, indehiscent capsular fruit with persistent calyx is compared with earlier reported dicot capsular fruits like Enigmocarpon parijae (Sahni,1943)is a 6-12 locular fruit with thick spongy wall, with a row of seeds in each locule. Harrisocarpon sahnii (Chitaley \& Nambudiri, 1973)and Sahniocarpon harrisii (Chitaley \& Patil, 1972) are similar in having pentalocular fruit. But, Harrisocarpon sahnii differ in having two seeds in each locule and Sahniocarpon harrisii vary in having perianth and triangular seed with septicidal dehiscence. Daberocarpon gerhardii (Chitaley \& Sheikh, 1973) differ as it is ten locular with single seed in each locule. Deccanocarpon arnoldii(Paradkar\& Dixit, 1975) vary as it is eight locular with single seed in each locule. Loculocidocarpon chitaleii (Kapgate, 1999) having pentalocular fruit but differ in having loculicidal dehiscence. Chitaleocarpon intertrappea (Kapgate, 2000) is a seven locular capsule with 2-8 seeds in each locule. Lythraceocarpon mohgaonese (Saxsena, 2004) is a hexalocular fruit with hexagonal central axis and 2-8 seeds per locule. Portulacaceocapon jamsavlii (Bhowal, Narkhede and Meshram,2011) is unilocular multiseeded capsular fruit.

Hence, the present petrified fruit is not showing exact similarity with any of the above reported fossil fruits. It is also compared with the modern (living) families of dicotyledons having capsular fruit like Polygalaceae, Theaceae, Tiliaceae,
Rutaceae, Malvaceae, Sapindaceae, Sterculiaceae, Geraniaceae, and Myrataceae. (Mathew 1983, Cooke 1958 \& B. Bhattacharyya, B.M. Johri, 1998)

In the families like Polygalaceae, Theaceae, Tiliaceae and Rutaceaefruits are dry capsule 3-5 celled but vary in having two ovules per locule. Family of Malvaceaeis similar in having persistent calyx but differ in having 3 or more seeds in each locule with curved embryo.

Fruit of family Sapindaceae differs in having arillate type of seed with loculicidal dehiscence. Likewise, in family Sterculiaceae fruits are dry, 2-5 celled usually schizocarpic with numerous ovules in each locule. In family Geraniaceae, fruit is generally five chambed with persistent calyx but style remains attached to the ovarian beak which is not in case of present one. In family Myrataceae fruit is with crown of calyx limb and angular seeds.

Thus from the above comparison it comes to the conclusion that present specimen could not be compared with any living and fossil genera. Hence, for the time being it is named as Pentaloculocarpon intertrappea gen. et sp. nov The generic name is after the pentalocular fruit and specific name is after the intertrappean beds.

$\begin{array}{lll}\text { Holotype } & : & \begin{array}{l}\text { APS. / Fruit }-1 . \\ \text { Department of } \\ \end{array} \\ & & \begin{array}{l}\text { Botany, Institute of } \\ \text { Science, Nagpur. }\end{array} \\ \text { Locality } & : & \text { Mohgaonkaln, M.P. } \\ \text { Horizon } & : & \begin{array}{l}\text { Deccan Intertrappean } \\ \text { Series of India. }\end{array} \\ \text { Age } & : & \text { Upper Cretaceous. }\end{array}$


Fig.1 Fruit shows Five Locules and Persistent Calyx. 25x; Fig.2 Enlarged Fruit wall or Pericarp with Presence of Few Canals; Fig.3 Fruit Showing Marginal Placentation. 25X

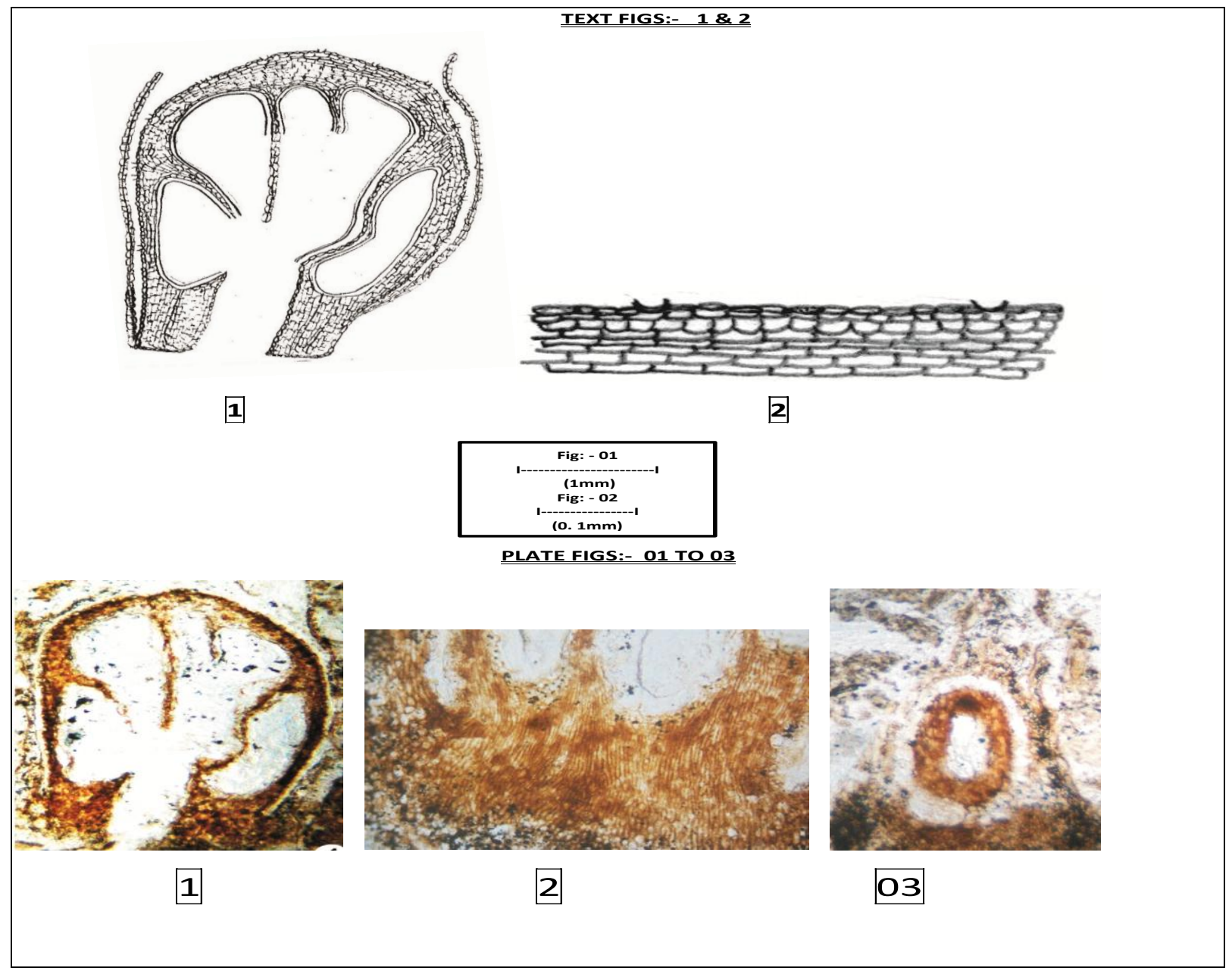

\section{References}

Bhattacharyya B. \&Johri B.M. Flowering plants. Narosa publishing house, New Delhi, Madras, Bombay, Calcutta, London. (1998)

Bhowal, M., Narkhede, S.D. and Meshram S.M. The taxonomic identification of unilocular angiospermic fruit from a new locality Jamsavli, M.P. India. BIONANO FRONTIER, Vol.4 (2):344-346. (2011).

Chitaley, S. D and Nambudiri, E.M.V. Harrisocarpon sahnii gen.et sp. nov.from deccan intertrappean bed of mohgaonkalan. Geophytology, 3: 3641. (1973)

Chitaley, S. D. \&Patil, G. V. Sahniocarpon harrisii gen. et. sp. nov from Deccan Intertrappean bed of India, Palaeobotanist vol. (29) : 288-292. (1972)

Chitaley, S. D. \& Sheikh, M. T. A ten locular petrified fruit from the deccan intertrappean series of India (1972) The Palaeobotanist Vol 20 (3): 297299. (1973)

Cook, C.I.E. The flora of the presidency of Bombay. Bot. Survey of India, Calcutta. B. (1958-67) 
Kapgate, V. D. A dicotyledonous capsular fruit from the deccan intertrappean bed of mohgaonkalan, M.P. India. Proc. XVI Int. Bot. Cong. St.locis : 948. (1999)

Kapgate, V.D. A seven locular petrified dicot fruit from the deccan intertrappean series of India. Proc. $6^{\text {Th }} \quad$ Int. Palaeobot. Con.Qinhuangdao.62. (2000)

Mathew, K. M. Flora of Tamilnadu carnatic. Part I,II,III, The Dicoeson press, India. (1983)

Paradkar, S.A \& Dixit, V. P. Deccanocarpon arnoldi gen.et. sp. nov. A new dicotyledonous fruit from the deccan intertrapean series of India. The Botanique 6 (1) : 5-10. (1975)

Sahni, B. Indian silicified plant Vol-II, Enigmocarpon parijae, a silicified fruit from the deccan with a review of fossil history of the Lythraceae. Proc. Ind. Acad. Sci. 17: 59-96. (1943)

Saxsena, N. N Angiospermic fossil flora of central India. Ph. D. Thesis, Nagpur University, Nagpur. (2004).

\section{How to cite this article:}

Khursel, A.S., and Narkhede, S.D. 2016. A new petrified pentalocular capsular fruit from the deccan intertrappean beds of Mohgaonkalan, M.P., India. Int.J.Curr.Microbiol.App.Sci. 5(4): 483-487. doi: http://dx.doi.org/10.20546/ijcmas.2016.504.057 